\title{
The Social Education Function of Hezhen Nationality Folk Proverb
}

\author{
Yang Guang \\ IBER, Harbin University of Commerce \\ Harbin, Heilongjiang province, 150028
}

\author{
Wang Hejiang, Ren Ping \\ Academy of the Humanities, Jiamusi University \\ Heilongjiang province, Jiamusi, 154007
}

\begin{abstract}
The Hezhen nationality in northeast minorities in the long historical process, gradually formed a unique characteristics of the fishing and hunting production folk proverbs, the Hezhen nationality folk proverbs in addition to entertainment, it has important social education function, the social education is embodied in pays attention to strengthen individual moral accomplishment, interpersonal relationship and coordination; Advocate the industrious and brave, hard work, and promote the development of social production; Emphasizing friend or foe, consolidate the Hezhen nationality masses; Establish Froude Marfa prestige, and promote the production and living of orderly; Folk-custom folkway, keep the Hezhen nationality features in five aspects, such as, Hezhen nationality society by giving full play to the social education function of folk proverbs, the Hezhen nationality society in food, turbulent times can still for production and life in good order, although Hezhen number less, but still indomitable vitality of stands on the northeast border areas. Hezhen nationality folk proverbs to accelerate the progress of the social economy, culture, and maintaining the traditional ethnic characteristics have important positive role. This paper has been collecting and collating folk proverbs and the society of Hezhen, to the area to the investigation, analysis and thinking about the meaning and connotation of the folk proverbs, summed up the social educational function of the folk proverbs, which is of great significance to understand and study the history and culture of Hezhen nationality.
\end{abstract}

Keywords—the Hezhen nationality; Folk proverbs; the social education; function

\section{INTRODUCTION}

Folk proverb is a concise language that describes the experience of production and life .Hezhen nationality is ethnic minorities of the northeast of the China. Hezhen nationality has a long history, the Hezhen tribe originated in the East China Sea jurchen. Mainly distributed in Heilongjiang Province, Tongjiang City, Fuyuan City, and Raohe County. Hezhen ethnic minority with a long history in northeast of China, although do not have to create the national characters, but the national oral culture is very rich, including folk proverb possesses an important position in the history of ethnic literature, sending out the charm of art.

Due to the social public and private education of the Hezhen Nationality until modern times appeared, therefore, in the long history of Hezhen nationality Education is accomplished by dictating and communicating, folk proverbs play an important role in it. "Proverbs play a very important role in the people's life, it can transfer production and life experience, educate the ethnic descendants, regulate people's behavior and the relationship between each other.'[1]. Hezhen nationality folk proverb contains rich ethics thought, teaching effect and moral significance, it has played an important role in the social education of the Hezhen nationality .Through the research on the social education function of Hezhen nationality folk proverbs, understand the cultural connotation and spirit is the core, to protect and promote the northeast minority intangible cultural heritage has historical value and practical significance.

\section{FOCUS ON STRENGTHENING PERSONAL MORAL}

\section{CULTIVATION, COORDINATION OF INTERPERSONAL}

\section{RELATIONSHIPS}

Children's education is crucial for a nation and the future development of the country, so each nation attaches great importance to early childhood education, Hezhen is no exception. The Folk Proverbs (hereinafter referred to as the Minyan) began to pay special attention to strengthen the personal moral self-cultivation from early childhood, childhood education, children the criteria for life, the purpose is to train good moral cultivation to coordinate social relations. Such as Hezhen proverb "proud to find friends, honest people everywhere have true friends", is the warns Hezhen children to be honest, not complacency. Only honest and honest people could make true friends, this is in order to interpersonal relationship more harmonious and orderly the society, but also to the society closely unite. In the long social population less, Hezhen area sparsely populated, "great fish roe deer gourd ladle scoop, pheasant flies into the rice cooker", rich natural resources, so the relationship of the relationship is not a competition, but cooperation relations, need to unite together, common development nature.

Personal strength hard against the attack of the beast and unpredictable natural disaster, only rely on the strength to resist, to solve the difficulties. So similar to the Hezhen nationality folk proverb which emphasis on solidarity are widely spread, such as "a mind the partnership, the loess into gold", "a drop of sweat, a fish, all full of sweat fish", "the 
rubber thread woven nets, a log cover no room" [2] and so on.

In order to strengthen unity and friendship, for the good things that are good for the collective, we should actively advocate; instead we should boycott them. Such as Hezhen proverb "good people doing good merit and elongating life, bad yourself, get better in the morning and evening", "the heart is not afraid of thunder, feet straight foot is not afraid of a crooked shoe." It emphasizes that people should do good, do well, and benefit others; and do bad things eventually would be punished, is to stop. The Hezhen nationality in the proverb "to be upright, the face value daughter", "human character, two people to have a conscience", and so on, these are emphasized children of Hezhen nationality to honest good, don't do things of betraying his face, This is the active training for children to form a good personality from the Hezhen nationality, have a certain guiding role.

In order to further standardize the social morality, the venerable old man on the basis of folk proverbs Hezhen write 15 words formula to the warning posterity, as follows:

"For fathers to supply, to respect the old man, for the dead to miss, for a wife to love, to the elder brothers to kind, sedate for sisters, for relatives to enthusiasm, be loyal to friends, for their children to discipline, for the enemy to hate, to the good tradition to preach, to bad habits to change and do things, to see fish fork, see the beast to play", this is helpful to Hezhen nationality social form good morality.

\section{ADVOCATING INDUSTRIOUS AND BRAVE, HARD WORK,}

\section{AND PROMOTE THE DEVELOPMENT OF SOCIAL PRODUCTION}

The Hezhen nationality is a brave and hardworking ethnic minorities, they are good at fishing in the river in the fish, but also good at hunting in the forest, so they have many fork about production and Practice Hezhen nationality is the typical fishing and hunting nationality in the northeast, so in collecting the proverb, including a large number of proverbs are visible around the fishing and hunting life, it also constitutes the Hezhen nationality characteristic of proverb. In order to encourage the fishing and hunting production and promote the social development, Hezhen folk proverb persuades children much work. Due to fishing and hunting production requires a certain, superb technology, cannot be separated from the accumulation of daily training, Hezhen folk proverb plays a guidance role: "water become a fork of the hand of god, not up the hill be good hunter", "harpoon don't touch to have, Mr. Gun not to rust", "archer more practice more, Mr Gun more tied more accurate", "river have gold (carp) and silver (salmon), depending on your hardworking not attendance", "the fish is a treasure, and to it" and so on, all these proverb encourages the Hezhen nationality children training, practice, work hard to get it good fish, become a dead shot.

The hunters hunting requires bold but cautious, therefore attaches great importance to encourage children brave, Hezhen enlightenment in education have been in the form of a proverb to pass on to future generations. Advocate the industrious and brave proverb everywhere, such as "bald waves not frighten the Hezhen", "the hunter afraid of wolves butch, fishermen waves", etc., these proverbs is the education of Hezhen industrious, brave are not afraid of the beasts ferocious and natural disasters come upon, be bold to develop natural, promote the further development of the Hezhen nationality society.

Hezhen proverb is no lack of emphasis on women also should actively engaged in the work, from the content of the Hezhen nationality in spring production folk proverb visible in the woman and man has a very clear division of labor, such as "man production is often in the outside, woman at home processing fish". This see Hezhen man production in the outside, and the women are staying home processing fish.

Hezhen proverb is one thousand years' experience of fishing and hunting activities and the summary of the law, use the most concise language expressed the fishing and hunting nationality generation must observe the behavior rule of fishing and hunting, such as: "shallow shoals for small fish, big river fish", Hezhen folk proverb on fishing and hunting production skills have "carp walk the line, the enlarged-end walk a large" and "wanted to listen to the wind, the fork to see water lines", "locust fish like deep water, the black bear like to make a blind pond", "one thousand tons of fish rapids in the deep, bite the fish in the shallow ditch", etc. to tell people the characteristics of the fishing and capture prey as well as the necessary conditions of itself.

In order to better according to the season of fishery production, Hezhen fisheries proverb arises at the historic moment: "summer fish, whole grain full fish; grain in ear fish lay eggs, the river stopped at the summer solstice, slight heat enlarged-end jump, great heat carp leap", this to scientifically has important guiding significance to catch fish.

\section{EMPHASIZE THE FRIEND OR FOE, HEZHEN NATIONALITY IN}

\section{UNITY TO CONSOLIDATE THE PUBLIC}

In the beginning of the 17 th century, Russia harassed the Hezhen tribe, the Hezhen nationality society correspondingly produced the "enemy" and "I", a concept of enemies and friends, and so on the proverb appellation is no longer simply refer to all the people, but a lot of the "enemy", the word "friend", such as "enemy to malicious, to oneself and". This period of the Hezhen nationality folk proverbs with particular emphasis on the enemy, friends, different attitude, such as "to a friend to the heart in heart, for the enemy to hard in hard", is also tell Hezhen people to unite and work together to be brave to face the enemy, to strengthen the unified national front Hezhen, make it stronger gradually.

After entering the modern, Hezhen social productive forces has been developed rapidly, the phenomenon of surplus products and private ownership gradually appeared in the society, the phenomenon that the gap between rich and poor is more and more obvious, therefore reflect on the Hezhen nationality folk proverb also involves more "he", "amount" and "peak" (note: "and he", "amount" and "peak" of the "rich" in nanai, "person", "the") with the Hezhen nationality between poor public proverb, these proverbs to 
emphasize the Hezhen nationality more poor people to unite, and these bullying "he", "amount" and "peak", to recognize the essence of oppression, namely "grilled fish is sweet, the heart of he is poison", "the Wolf want to eat people, mountain main bully hunter", "ten the true, nine oppressed hunters"[3].

Hezhen guileless simple, fishing and hunting people tend to be vicious man with a bottle of wine, a ruler cloth will buy for the so-called "friends". Frequent Russian profiteers with a bag of tobacco leaf is easily for Hezhen precious mink, even when they are willing to lose, Hezhen also thinks "it's good to merchant told us". In order to resist the temptation of reactionary forces, emphasize to draw a line on both in the proverb to consolidate the Hezhen nationality united front against the dark forces. Such as Hezhen proverb "often use the technique of metaphor, that people of different interests circles to coexist together: 'the Wolf and the sheep no friends, the eagle and chicks in less than a piece of", "the fox said with bolshoy ussuriysky make no friends, and so on" [4], in the form of analogy to illustrate class antagonism.

This period of proverbs in different degree, and reflects the Hezhen nationality people "who", "amount" and "peak", hate for their unearned behavior to have the strong effect so as to arouse the unifying of labor the people fighting against the greed of the ruling class, to maintain the unity of the mass society and the strong.

\section{ESTABLISH FROUDE MARFA PRESTIGE, AND PROMOTE THE} PRODUCTION AND LIVING OF ORDERLY

In the early society of Hezhen nationality, without judicial arbitration institutions of civil disputes is dependent on Froude Marfa (note: The Marfa is the oldest and most experienced leader of a nation or tribe) to coordinate or arbitration. Both in production and life any fishing production problems encountered in the possession, such as production tools and the use, production process of the organization and division of labor, exchange and distribution of production results in the need to laud method for scheduling, so the responsibility of the method of law. Tend to be older, fishing and hunting, experienced, high credibility, fair people through democratic elections.

In order to maintain the status of the law, and make the Hezhen nationality society orderly, folk proverb fully establish the prestige of law. Hezhen nationality fishing young hand to listen to fatigue to inculcate Marfa, cannot little, such as "Go out to look at the sky, to fish in the river must be experienced to consult the elderly "[5].

Lauder Marfa Hezhen also play a vital role in nationality relationship between labor members, "it is said that in the early years of the Hezhen collective out hunting, lowe $M$ hair using proverb to help resolve the dispute" the hunter between [6]. In order to make the children to obey the reasonable arrangement of Hezhen, Hezhen Well-known saying virtually plays a role of the common law. Such as lauder Marfa emphasizes the distribution according to work, when allocating work corresponding Hezhen proverb: "more hit points, less points" occurs, illustrates the work achievement is closely connected with how much labor, just pay more sweat, have more harvest.

Hezhen nationality colloquial and widespread "meet half", is in the process of the Hezhen nationality in hunting, if there is a hunter played a prey, and happened to be a passer-by at this time, so the hunter took the prey to the passers-by, which fully reflects the Hezhen nationality love and honest folkway, humility is actually Hezhen law emphasizes is the embodiment of the principle of fraternal.

\section{THE FOLK-CUSTOM FOLKWAY, HEZHEN ETHNIC}

\section{CHARACTERISTICS}

As Hezhen language in daily communication is replaced by Chinese, although Hezhen nationality proverb spread in one thousand are now in the Chinese language as a carrier for records and records, which has the typical characteristics of fishing and hunting nationality are still sending out the unique charm. Many of Hezhen proverb is unique to it nation, directly reflects the simple folk customs, such as "There are a lot of fish in Heilongjiang, Songhua River and Ussuri river", And so on.

Owing to the rap proverb has a certain randomness, in the absence of spiritual sustenance in the society of Hezhen nationality, the folk proverb undoubtedly plays an important role, is a good way to edify sentiment and cheerful mood. Proverb is Hezhen after thousands of years and the long, the reason is that it can make the Hezhen nationality fishing people get happy, spirited and radical who are in a dilemma, arouse the sense of national pride and love of nature.

Because since the Ming and Qing dynasties Hezhen society influx immigrants, the folk proverb is also reflected in many other nations in common, appeared a lot of similar proverb in northeast China, one of the most famous proverb "great fish roe deer gourd ladle scoop, pheasant flies into the rice cooker", "three big treasure - northeast ginseng, mink, $\mathrm{Wu}$ La grass", etc., products rich in northeast vividly described. At this point has been incorporated into the northeast Hezhen ethnic family, its national folk proverb also belongs to the northeast proverb. Such as "Hu potato stir raccoon oil surface and slippery", "pheasant braise powder, chicken powder, delicious, delicious not mow chopsticks, sooner or later get a belly". The proverb spread in the Hezhen nationality society, not only in the northeast minority has spread of other embodies the Hezhen nationality society and other social blend to deepen. With the changing times, the Hezhe traditional culture is changing, especially the mass flow, Hezhe traditional culture has been a great impact, in order to collect and preserve the folk proverbs and folk literature, save the excellent traditional culture, "a text, static protection by means of recording, but also need to build dynamic protection platform"[7].

\section{CONCLUSION}

The times are changing, the cultivation and education of talents is the hope of a nation and even a country, and education is not only dependent on the classroom education of the school, but also plays an important role in the social 
and family education. The important value of folk proverbs is to take social and family education way to inherit and develop the essence of traditional culture, so that people can take the popular way to understand and master the excellent traditional culture, and passed down from generation to generation. A proverb is a folk collective creation, wide mouth, concise and comprehensive and more stereotypical artistic statement, is a regular summary of people wisdom and rich experience. Proper use of proverbs can make the language lively and interesting, and enhance the performance of the article. Proverbs are widely spread in the folk spoken language, expressing people's rich experience in social life, shining the light of people's wisdom. People in the use of proverbs in speaking and writing, can make the image of the language, vivid, and enhance the effect of expression. Although the ancient social Hezhen without any paper and pen, noted with rope, but folk proverb connotation is rich and strong educational. Understand the folk proverb not only helps to understand the past cultural life, spiritual beliefs, folk customs, but also can be seen the folk proverb plays an indispensable role in the society of Hezhen Nationality at that time, has a positive and important social education function. Even in today's society minority proverb still has certain general education of popular practical significance. The role of proverbs is very large, we should inherit and carry forward the China minority proverb, full of traditional minority culture research Chinese, protect and inherit the traditional culture of the Chinese nation, is our contemporary every citizen ought to do the duty. Not only is the other minority, in Chinese is also popular with many folk proverbs, these embodies the wisdom and knowledge of the national traditional culture, now more and more attention by people. In some areas of China, school education is not only to learn foreign languages, science and other disciplines, but also opened the history and culture of ethnic minorities in the disciplines of history and culture, there are some folk proverbs knowledge. There are young parents attach great importance to the traditional historical and cultural education of the children, the children are very young, and encourage them to recite and understand the Chinese traditional culture, including folk proverbs, which is very meaningful.

\section{ACKNOWLEDGMENT}

The fifty-sixth group of department Chinese Postdoctoral Science Fund supported project (2014M561368); in 2015 in Heilongjiang province philosophy social sciences research planning project, project number (15 MZE01)

\section{REFERENCES}

[1] YouJinLiang. Hezhen picked Jane [M]. Jiamusi, Heilongjiang province Jiamusi federation of literature and art, 1988, p. 295.

[2] Xu Changhan, yellow Ren Yuan. Hezhen nationality literature [M]. Harbin: the art and literature press, 2000, p. 418

[3] Huang Ze, misleading. Hezhen nationality township - Heilongjiang with jin jiang city street mouth survey [M]. Kunming: yunnan university press. 2004. 204 nights.

[4] He Xuejuan among all nations, xu. The present situation and the development research [M]. Beijing: China social sciences press, 2008, p. 99.

[5] Shiqing Wang, wang product letter, Lv Pin. Hezhen fish culture [j]. Harbin: heilongjiang education publishing house. 2011. P. 232.

[6] Xu Changhan, yellow Ren Yuan. Hezhen nationality literature [M]. Harbin: the art and literature press, 2000, p. 418.

[7] Yangguang. The social and cultural changes Changchun [M]. Jilin Literature Press, 2014, 220. 